\title{
DAMPAK EFISIENSI USAHATANI PADI TERHADAP PENINGKATAN PRODUKTVITAS
}

\author{
Sulistyorini ${ }^{*}{ }^{* 1)}$, Lasmono Tri Sunaryanto ${ }^{2)}$ \\ 1) Program Studi Agribinsis Fakultas Pertanian Dan Bisnis Universitas Kristen Satya Wacana \\ 2) Fakultas Pertanian Dan Bisnis Universitas Kristen Satya Wacana \\ *) E-mail Penulis Korespondensi: 522015065@student.uksw.edu
}

\begin{abstract}
ABSTRAK
Usahatani padi di Desa Kutukan dijalankan pada dua jenis lahan yang berbeda yaitu lahan irigasi dan tadah hujan. Perbedaan lahan ini akan mengakibatkan efisiensi dan produktivitas berbeda. Produktivitas yang tinggi menunjukkan bahwa usahatani efisien. Penelitian ini bertujuan untuk : (1) Membandingkan pendapatan usahatani padi; (2) Membandingkan efisiensi usahatani; (3) Mengetahui faktor produksi yang mempengaruhi produktivitas padi; serta (4) mengetahui perbedaan penggunaan faktor produksi pada usahatani padi. Jenis penelitian ini adalah penelitian deskriptif dengan pendekatan kuantitatif. Analisis data yang digunakan adalah analisis pendapatan, analisis efisiensi dan analisis faktor produksi dengan fungsi produksi Cobb-Douglas. Teknik pengambilan sampel mengunakan tehnik accidental sampling untuk lahan irigasi dengan responden sebanyak 30 petani sedangkan untuk lahan tadah hujan karena responden hanya ada 25 sehingga sampel diambil dengan metode sensus. Hasil analisis menunjukkan bahwa produktivitas padi lahan irigasi dan lahan tadah hujan masing-masing sebesar $74,12 \mathrm{Kw} / \mathrm{Ha}$ dan $59,17 \mathrm{Kw} / \mathrm{Ha}$. Pendapatan usahatani padi lahan irigasi lebih tinggi jika dibandingkan dengan usahatani padi lahan tadah hujan. Efisiensi usahatani padi lahan irigasi dan lahan tadah hujan tidak berbeda nyata dan masing-masing memiliki efisiensi sebesar $R / C$ rasio 2,43 dan $R / C$ rasio 2,38. Produktivitas padi di Desa Kutukan dipengaruhi oleh jenis lahan, jumlah pupuk urea dan tenaga kerja. Terdapat perbedaan yang signifikan dalam penggunaan bibit, urea, dan pestisida, sedangkan penggunaan SP36 dan tenaga kerja tidak ada perbedaan yang signifikan. Penggunaan bibit dan urea pada lahan tadah hujan lebih tinggi jika dibandingkan lahan irigasi dan penggunaan pestisida pada lahan irigasi lebih tinggi daripada lahan tadah hujan.
\end{abstract}

Kata kunci: Efisiensi Usahatani; Produktivitas; Pendapatan Lahan Irigasi; Pendapatan Lahan Tadah Hujan

\section{PENDAHULUAN}

Indonesia adalah negara agraris yang sebagian besar penduduknya bekerja sebagai petani, sehingga pertanian menjadi sektor yang memegang peranan penting dalam perekonomian Indonesia. Di tahun 1981 sebanyak 24,5\% pendapatan nasional diperoleh dari sektor pertanian dan mampu menyerap tenaga kerja sebanyak 54,8 \% di tahun 1980 (Widodo, 1989). Beras menjadi salah satu komoditas pertanian yang memiliki peranan penting dalam ketahanan pangan karena beras merupakan sumber bahan pangan utama bagi sebagian besar masyarakat Indonesia. Beras memberikan peran hingga $45 \%$ dari total food intake atau sekitar $80 \%$ dari sumber karbohidrat utama dalam pola konsumsi masyarakat (Arifin, 2007).

Semakin meningkatnya laju pertumbuhan penduduk maka kebutuhan beras akan semakin meningkat. Kebutuhan yang tinggi harus diikuti dengan peningkatan jumlah produksi agar tidak timbul permasalahan. Pemerintah sejak awal telah memberikan 
perhatian khusus tentang kebijakan beras nasional. Beberapa program untuk meningkatkan produksi beras nasional telah dilakukan seperti perluasan areal tanam, pengembangan benih, pengembangan kelembagaan, pengolahan dan pemasaran hasil serta pengembangan sarana dan prasarana berupa penyediaan saprodi dan perbaikan jaringan irigasi untuk memaksimalkan produksi padi pada lahan tadah hujan, salah satunya di Kabupaten Blora yang sebagian besar wilayahnya lahan pertanian (Litbangtan, 2005).

Kabupaten Blora memiliki potensi lahan pertanian padi seluas 46.620 ha. yang terdiri dari 15.094 ha. sawah irigasi dan 31.526 ha. sawah tadah hujan. Dengan luas lahan yang ada, produktivitas padi di Kabupaten Blora pada tahun 2017 mencapai 5,4 ton/ha sehingga Kabupaten Blora menjadi salah satu penyuplai beras terbesar keempat di Jawa Tengah. Luas panen, produksi dan produktivitas padi di Kabupaten Blora selama enam tahun terakhir dapat dilihat pada Tabel 1.

Tabel 1 Luas Panen, Produksi dan Produktivitas Padi Kabupaten Blora

\begin{tabular}{|c|c|c|c|c|c|}
\hline \multirow[b]{2}{*}{ Tahun } & \multicolumn{2}{|c|}{ Padi Irigasi } & \multicolumn{2}{|c|}{ Padi Tadah Hujan } & \multirow[b]{2}{*}{$\begin{array}{l}\text { Produktivitas total } \\
\text { (Ton/Ha) }\end{array}$} \\
\hline & $\begin{array}{l}\text { Luas panen } \\
\text { (Ha) }\end{array}$ & $\begin{array}{l}\text { Produksi } \\
\text { (Ton) }\end{array}$ & $\begin{array}{l}\text { Luas panen } \\
\text { (Ha) }\end{array}$ & $\begin{array}{l}\text { Produksi } \\
\text { (Ton) }\end{array}$ & \\
\hline 2012 & 75.605 & 402.874 & 3.955 & 19.221 & 5,30 \\
\hline 2013 & 78.390 & 409.357 & 5.870 & 25.545 & 5,16 \\
\hline 2014 & 74.936 & 392.506 & 7.796 & 35.710 & 5,17 \\
\hline 2015 & 80.877 & 403.067 & 10.470 & 35.724 & 4,80 \\
\hline 2016 & 83.739 & 474.886 & 14.388 & 57.869 & 5,42 \\
\hline 2017 & 89.207 & 504.711 & 20.820 & 95.608 & 5,45 \\
\hline
\end{tabular}

Sumber : BPS Kabupaten Blora 2018

Produktivitas padi di Kabupaten Blora mengalami fluktuasi selama enam tahun terakhir. Di tahun 2016 dan 2017 luas panen padi bertambah yang diikuti dengan meningkatnya produktivitas padi, namun peningkatan ini masih berada dibawah produksi potensial, sehingga produktivitasnya masih dikatakan rendah.

Produktivitas yang rendah menunjukkan indikator bahwa usahatani tersebut belum efisien. Akan tetapi produktivitas masih bisa ditingkatkan dengan memanfaatkan potensi lahan lainnya seluas 35.677 ha. (Dinas Pertanian dan Ketahanan Pangan Kabupaten Blora). Lahan tersebut merupakan lahan kering yang bibitnya siap tanam tetapi belum bisa ditanam akibat lahan kekurangan air. Luas panen dan produksi padi dipengaruhi oleh musim tanam dan ketersediaan air irigasi (Yoko, et al. 2014). Jika air tersedia terus menerus sepanjang tahun maka petani memiiki kecenderungan untuk menanam padi dalam sepanjang tahun tersebut, sehingga luas panen dan jumlah produksi akan meningkat.

Menurut Mubyarto (1989) produktivitas yang tinggi menandakan bahwa usahatani tersebut sudah efisien. Peningkatan produktivitas dapat dilakukan dengan intensifikasi atau perbaikan teknologi seperti perbaikan sistem irigasi. Salah satunya penggunaan sistem irigasi proyek pengembangan air tanah (P2AT) yang ada. Irigasi P2AT merupakan irigasi dari pengembangan air tanah (sumur) dimana penggunaannya masih terbatas sehingga petani yang memiliki lahan jauh dari sumur masih menjalankan usahataninya pada lahan tadah hujan. Perbedaan sistem usahatani ini akan mempengaruhi produktivitas yang dihasilkan, maka analisis efisiensi ini perlu dilakukan. Penelitian ini bertujuan untuk: 1) membandingkan produktivitas dan pendapatan usahatani padi lahan irigasi P2AT dan lahan tadah hujan; 2) membandingkan efisiensi usahatani padi irigasi P2AT dengan lahan tadah hujan; dan 3) mengetahui perbedaan penggunaan faktor produksi yang mempengaruhi produktivitas padi pada lahan irigasi P2AT dan lahan tadah hujan.

\section{METODE}

Penelitian ini dilaksanakan di Desa Kutukan Kecamatan Randublatung Kabupaten Blora. Pemilihan lokasi penelitian berdasarkan pertimbangan bahwa di Desa Kutukan sebagian besar masyarakatnya berusahatani padi dan terdapat perbedaan sistem 
usahataninya yaitu lahan basah dan lahan kering. Jenis penelitian ini adalah penelitian deskriptif dengan pendekatan kuantitatif. Pengumpulan data penelitian dilakukan dengan metode wawancara mendalam (indepth interview) menggunakan kuesioner, observasi dan dokumentasi. Teknik pengambilan sampel mengunakan accidental sampling untuk lahan irigasi dengan responden sebanyak 30 petani sedangkan untuk lahan tadah hujan karena responden hanya ada 25 sehingga sampel diambil dengan metode sensus. Analisis yang digunakan adalah analisis pendapatan, analisis efisiensi dan analisis faktor produksi dengan fungsi produksi Cobb-Douglas. Tehnik analisis data masing-masing dijelaskan sebagai berikut :

\section{Analisis Pendapatan dan Efisiensi}

Pendapatan usahatani merupakan selisih antara penerimaan atau pendapatan kotor dengan pengeluaran total. Pendapatan dapat dihitung dengan rumus :

$$
\Pi=\mathrm{TR}-\mathrm{TC}
$$

Dimana :

$\Pi \quad$ : Pendapatan Usahatani (Rp)

TR : : Total Penerimaan (Rp)

TC : Total Biaya $(\mathrm{Rp})$

Pendapatan petani dinyatakan lebih besar apabila usahatani yang dilakukan efisien, dalam artian biaya yang dikeluarkan untuk penggunaan faktor produksi minimal dengan menghasilkan produksi yang maksimal. Analisis efisiensi usahatani dihitung dengan membandingkan penerimaan dengan biaya produksi (R/C rasio) dengan rumus :

$\mathrm{R} / \mathrm{C}$ rasio $\geq 1$ usahatani sudah efisien

$$
R / C=\frac{\text { Penerimaan }}{\text { Biaya total }}
$$

$\mathrm{R} / \mathrm{C}$ rasio $<1$ usahatani belum efisien

Perbandingan produktivitas, pendapatan dan efisiensi usahatani dihitung dengan menggunakan uji t-test.

\section{Analisis Fungsi Produksi Cobb-Douglas}

Pendekatan fungsi produksi Cobb-Douglas digunakan untuk mengetahui faktor-faktor yang mempengaruhi produksi padi pada lahan irigasi P2AT dan lahan tadah hujan. Persamaan fungsi produksi Cobb-Douglas secara matematis adalah sebagai berikut (Soekartawi, 2002) :

$$
Y=a X_{1}{ }^{b 1} X_{2}{ }^{b 2} \ldots X_{i}^{b i} \ldots X_{n}{ }^{b n} e^{n}
$$

Agar fungsi produksi tersebut mudah dipahami dan ditafsirkan maka diubah kedalam bentuk linear berganda dengan me-logaritma-kan persamaan di atas sehingga menjadi :

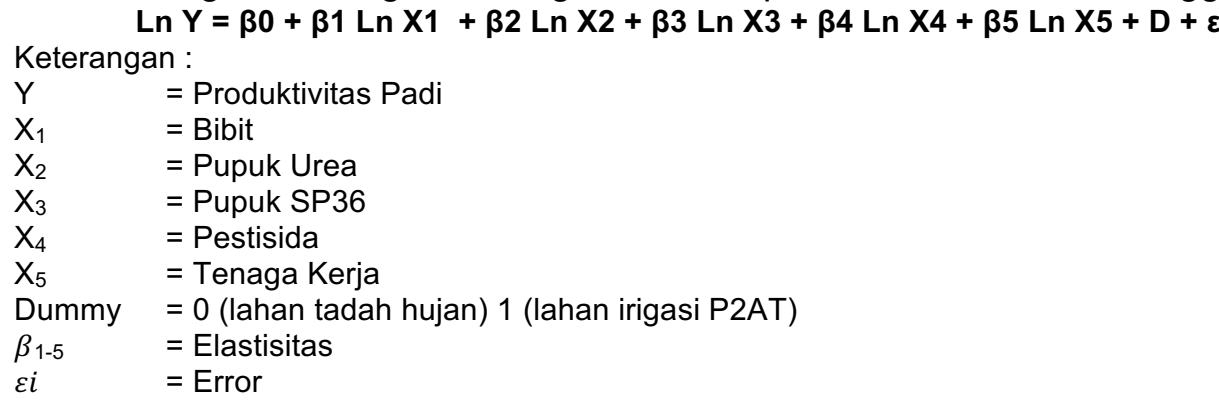

\section{HASIL DAN PEMBAHASAN}

\section{Perbandingan Produktivitas, Pendapatan dan Efisiensi Usahatani Padi Lahan Irigasi P2AT dan Lahan Tadah Hujan \\ Perbandingan produktivitas, pendapatan dan efisiensi antara usahatani padi irigasi P2AT dan tadah hujan dianalisis dengan uji perbandingan t-test. Hasil uji t-test disajikan pada Tabel 2 di bawah ini :}


Tabel 2 Hasil Uji t-test

\begin{tabular}{|c|c|c|c|}
\hline \multirow{2}{*}{ Uraian } & \multicolumn{2}{|c|}{ Mean } & \multirow{2}{*}{$\begin{array}{c}\text { Sig. } \\
\text { (2 tailed) }\end{array}$} \\
\hline & Irigasi P2AT & Tadah hujan & \\
\hline Pendapatan & 17.892 .096 & 13.209 .235 & 0,000 \\
\hline Efisiensi & 2,43 & 2,38 & 0,225 \\
\hline
\end{tabular}

Dari Tabel 2 pendapatan pada usahatani padi lahan irigasi P2AT lebih tinggi jika dibandingkan dengan usahatani padi lahan tadah hujan. Penelitian ini sejalan dengan penelitian (Noviani, et al. 2018) yang menyatakan bahwa pendapatan antara usahatani padi irigasi dan tadah hujan berbeda, pendapatan pada usahatani padi irigasi lebih tinggi dari pada usahatani padi tadah hujan. Pendapatan usahatani padi lahan irigasi P2AT sebesar Rp 17.892.096 sedangkan pendapatan usahatani padi tadah hujan sebesar Rp 13.209.235. Perbedaan pendapatan ini dipengaruhi oleh hasil produksi padi irigasi P2AT yang lebih tinggi. Perbedaan produksi ini dipengaruhi oleh ketersediaan air selama proses produksi, karena secara agronomi budidaya padi dengan ketersediaan air yang baik maka akan menghasilkan produksi yang lebih tinggi jika dibandingkan dengan budidaya padi yang kekurangan air.

Berdasarkan uji perbandingan (t-test) efisiensi bahwa tidak ada perbedaan yang nyata antara efisiensi usahatani padi irigasi dengan usahatani padi tadah hujan atau dapat diartikan bahwa efisiensi usahatani padi lahan irigasi dan lahan tadah hujan sama. Penelitian ini tidak sejalan dengan penelitian Sitinjak (2019) yang menyatakan bahwa nilai $\mathrm{R} / \mathrm{C}$ rasio untuk usahatani padi irigasi lebih besar dari pada usahatani tadah hujan, sehingga usahatani padi lahan irigasi lebih efisien jika dibandingkan dengan usahatani padi tadah hujan. Efisiensi usahatani padi irigasi dan tadah hujan di Desa Kutukan sama karena efisiensi tidak hanya dilihat pada produktivitas dan penerimaan yang tinggi namun juga jumlah biaya yang dikeluarkan. Usahatani padi irigasi memiliki penerimaan yang lebih tinggi namun biaya yang dikeluarkan juga cukup tinggi, sedangkan usahatani padi tadah hujan penerimaan yang didapat lebih rendah tetapi biaya yang dikeluarkan lebih sedikit karena pada lahan tadah hujan tidak perlu mengeluarkan biaya pengairan. Petani padi lahan irigasi harus mengeluarkan biaya yang cukup besar untuk pengairan, biaya ini mencapai Rp 500.000 untuk luas lahan $2500 \mathrm{~m}^{2}$ atau sekitar Rp 2.000.000/ha. Menurut Hernanto (1991) efisiensi usahatani dapat ditingkatkan dengan meningkatkan penerimaan atau mengurangi biaya usahatani.

\section{Faktor - Faktor Produksi yang Mempengaruhi Produktivitas Usahatani Padi Lahan Irigasi P2AT dan Lahan Tadah Hujan}

Hasil analisis regresi linier berganda dalam penelitian ini dapat dilihat pada Tabel 3. Faktor-faktor yang mempengaruhi produksi padi dapat dilihat menggunakan model persamaan regresi linier berganda berikut ini :

$$
\begin{aligned}
\operatorname{LnY}= & 11,426+0,091 \operatorname{LnX}_{1}-0,158 \operatorname{LnX}_{2}-0,078 \operatorname{LnX}_{3}+0,003 \operatorname{LnX}_{4}+0,363 \operatorname{LnX}_{5}+ \\
& 0,202 \text { dummy }
\end{aligned}
$$

Tabel 3 Hasil Analisis Regresi Linier Berganda

\begin{tabular}{lcccc}
\hline \multicolumn{1}{c}{ Variabel Penelitian } & $\begin{array}{c}\text { Parameter } \\
\text { Dugaan }\end{array}$ & Std.Error & Thitung & Sig. (2 Tailed) \\
\hline (Constanta) & 11,426 & 0,799 & 14,306 & 0,000 \\
Dummy & 0,202 & 0,043 & 4,678 & $0,000^{*}$ \\
LnBibit (X1) & 0,91 & 0,160 & 0,569 & 0,572 \\
LnUrea (X2) & $-0,158$ & 0,077 & $-2,055$ & $0,045^{*}$ \\
LnSP36 (X3) & $-0,078$ & 0,050 & $-1,563$ & 0,125 \\
LnPestisida (X4) & 0,003 & 0,077 & 0,038 & 0,970 \\
Ln Tenaga kerja (X5) & 0,363 & 0,155 & $-2,345$ & $0,023^{*}$ \\
& & & & \\
Fhitung & 12,566 & & & \\
R-Squere & 0,611 & & & \\
Adjusted R-Square & 0,562 & & & \\
Sumber : Data primer diolah, 2019 & &
\end{tabular}




\section{Pengaruh Jenis Lahan Terhadap Produktivitas Padi}

Variabel Dummy memiliki nilai nilai signifikansi 0,000 $<0,05$ maka dapat disimpulkan bahwa jenis lahan berpengaruh signifikan terhadap produktivitas padi. Dari nilai koefisien regresi 0,202 menunjukan bahwa lahan irigasi P2AT lebih baik dari pada lahan tadah hujan, dengan perbedaan sebesar 0,202 . Salah satu penyebab jenis lahan berpengaruh terhadap produksi padi adalah petani lahan irigasi mampu mengontrol kebutuhan air untuk tanaman padinya sedangkan petani dengan lahan tadah hujan hanya mampu mengandalkan air hujan.

\section{Pengaruh Jumlah Bibit Terhadap Produktivitas Padi}

Variabel jumlah bibit memiliki nilai signifikansi 0,572 $>0,05$ maka dapat dijelaskan bahwa variabel bibit tidak berpengaruh nyata terhadap produktivitas padi. Penelitian ini tidak sejalan dengan dengan penelitian Wibowo (2012) yang menyatakan bahwa bibit berpengaruh nyata terhadap produktivitas padi, penggunaan bibit unggul dan bersertifikat serta jumlah yang sesuai akan mempengaruhi produktivitas padi. Bibit dalam penelitian ini tidak berpengaruh terhadap produktivitas yang dihasilkan karena penggunaannya yang berlebihan tidak sesuai anjuran. Menurut Badan Penelitian dan Pengembangan Pertanian (Litbangtan) penggunaan bibit padi untuk luas lahan 1 hektar adalah 20-25 kg sedangkan dalam penelitian ini bibit yang digunakan petani untuk lahan 1 hektar mencapai $40 \mathrm{~kg}$.

\section{Pengaruh Jumlah Urea Terhadap Produktivitas Padi}

Nilai signifikansi variabel pupuk urea (X2) adalah $0,045<0,05$, hasil tersebut menunjukan bahwa penggunaan urea berpengaruh nyata terhadap produktivitas padi yang dihasilkan. Nilai koefisien regresi sebesar -0,158 menunjukan bahwa setiap penambahan $1 \%$ urea untuk usahatani padi yang dijalankan akan menurunkan produktivitas padi sebesar $15,8 \%$. Nilai koefisien regresi jika dihubungkan dengan fungsi produksi CobbDouglas menunjuk pada kondisi elastisitas produksi lebih kecil dari $0(e p, 0)$. Keadaan tersebut dapat dijelaskan bahwa urea berada pada kondisi produksi marginal yang negatif atau berada pada daerah yang irasional. Hal itu terjadi karena penggunaan urea yang sudah berlebihan atau penggunaan urea yang sudah berada pada titik kejenuhan, sehingga penambahan urea bukan meningkatkan produksi tetapi malah sebaliknya. Menurut Apriyantono (2007) penggunaan urea yang dianjurkan untuk luas lahan 1 ha. adalah 200$250 \mathrm{~kg}$., sedangkan dalam penelitian ini petani menggunakan pupuk urea mencapai 300$400 \mathrm{~kg}$. untuk 1 hektarnya.

\section{Pengaruh Jumlah SP36 Terhadap Produktivitas Padi}

Variabel SP36 (X3) memiliki nilai signifikansi 0,125 > 0,05 sehingga variabel SP36 tidak berpengaruh nyata terhadap produktivitas padi. Penggunaan SP36 tidak berpengaruh terhadap produksi padi hal ini diduga karena penggunaan SP36 yang berlebihan, petani menggunakan pupuk SP36 sebanyak $250 \mathrm{~kg}$./ha.. Berdasarkan peraturan pemerintah tentang rekomendasi penggunaan pupuk pada tanaman padi penggunaan SP36 untuk luas lahan 1 ha. adalah 150-200 kg. Penelitian ini sejalan dengan penelitian Fermadi, et al. (2015) yang menyatakan bahwa penggunaan pupuk SP36 tidak berpengaruh terhadap produksi jagung dikarenakan penggunaannya yang tidak sesuai anjuran. Pupuk sangat dibutuhkan oleh tanaman namun penggunaannya harus sesuai kebutuhan. Penggunaan pupuk yang berlebihan akan merusak tanah dan lingkungan. Sesuai dengan pendapat Triyono et al. (2013) yang menyatakan bahwa penggunaan pupuk anorganik yang tidak terkontrol akan menurunkan kualitas tanah.

\section{Pengaruh Pestisida Terhadap Produktivitas Padi}

Variabel Pestisida (X4) memiliki nilai signifikansi 0,970 >0,05 maka dapat dikatakan bahwa pestisida tidak berpengaruh nyata terhadap produktivitas padi. Hal tersebut sejalan 
dengan penelitian Wibowo (2012) yang menyatakan bahwa pestisida tidak berpengaruh terhadap produksi padi. Yuliana (2016) berpendapat bahwa pestisida tidak berpengaruh terhadap produksi padi karena zat yang terkandung di dalam pestisida hanya berfungsi untuk membasmi hama dan penyakit tidak mempengaruhi pertumbuhan tanaman. Sejalan dengan pendapat Purwono (2007) yang menyatakan bahwa pestisida dibutuhkan petani untuk mencegah serta membasmi hama dan penyakit pada tanaman.

\section{Pengaruh Tenaga Kerja Terhadap Produktivitas Padi}

Variabel Tenaga Kerja (X5) memiliki memiliki nilai signifikansi 0,023 $<0,05$ yang berarti bahwa tenaga kerja berpengaruh nyata terhadap produktivitas padi. Nilai koefisien regresi sebesar 0,363 menunjukkan bahwa setiap penambahan $1 \%$ tenaga kerja maka akan meningkatkan produktivitas sebesar $36,3 \%$. Penelitian ini sejalan dengan penelitian Wibowo (2012) yang menyatakan bahwa tenaga kerja berpengaruh terhadap produksi padi. Mubyarto (1995) menyatakan bahwa tenaga kerja merupakan aspek penting dalam memperoleh output dalam pengelolaan produksi. Tenaga kerja jika penggunaannya sesuai dengan kebutuhan maka akan menentukan keberhasilan dalam usahataninya. Tenaga kerja masih dapat ditambah karena menurut Hernanto (1991) standar tenaga kerja untuk produksi padi adalah $159 \mathrm{HOK} / \mathrm{ha}$.. Penambahan tenaga kerja yang memiliki pengalaman dan pengetahuan yang baik akan meningkatkan produktivitas padi yang dihasilkan.

\section{Perbedaan Penggunaan Faktor - Faktor Produksi yang Mempengaruhi Produktivitas Usahatani Padi Irigasi P2AT dan Padi Tadah Hujan}

Faktor produksi yang digunakan berupa bibit, urea, SP36, pestisida dan tenaga kerja. Perbedaan faktor produksi dianalisis untuk mengetahui jumlah faktor produksi yang digunakan oleh petani. Perbedaan penggunaan faktor-faktor produksi diperoleh dari hasil analisis uji t-test, hasil uji tersebut disajikan pada Tabel 4 dibawah ini :

Tabel 4 Hasil Uji t-test

\begin{tabular}{|c|c|c|c|c|c|}
\hline \multirow[b]{2}{*}{ No } & \multirow[b]{2}{*}{ Variabel } & \multicolumn{2}{|c|}{ Mean } & \multirow[b]{2}{*}{ Sig. (2 tailed) } & \multirow[b]{2}{*}{ t-hitung } \\
\hline & & Irigasi & Tadah Hujan & & \\
\hline 1. & Benih & 39,28 & 47,14 & 0,000 & 5,744 \\
\hline 2. & Urea & 341,25 & 439,08 & 0,000 & 4,558 \\
\hline 3. & SP36 & 232,59 & 210,59 & 0,304 & 1,039 \\
\hline 4. & Pestisida & 0,434 & 0,36 & 0,001 & 3,622 \\
\hline 5. & Tenaga Kerja & 109,59 & 115,39 & 0,143 & 1,504 \\
\hline
\end{tabular}

Sumber: Data primer diolah, 2019

\section{Penggunaan Bibit}

Berdasarkan tabel uji perbandingan dapat dilihat bahwa terdapat perbedaan penggunaan benih antara usahatani padi irigasi P2AT dengan usahatani padi tadah hujan. Rata-rata penggunaan benih pada lahan irigasi P2AT sebanyak 39,28 sedangkan pada lahan tadah hujan sebanyak 47,14 lebih banyak jika dibandingkan dengan padi lahan irigasi. Hal tersebut sejalan dengan penelitian (Indah et al. 2015) yang menyatakan bahwa penggunaan benih padi pada lahan tadah hujan lebih banyak dari pada lahan irigasi pada musim tanam pertama.

Perbedaan penggunaan benih ini dipengaruhi oleh varietas jenis lahan yang ditanami. Pada lahan irigasi kebutuhan air lebih mudah diatur sehingga keberlangsungan hidup benih yang telah disemai dan bibit yang telah dipindah tanam dapat dijamin, sedangkan pada lahan tadah hujan kebutuhan air sangat tergantung oleh cuaca. Banyak bibit yang mati setelah pindah tanam karena kekurangan air atupun kelebihan air, sehingga petani tadah hujan lebih banyak menyemai benih untuk menyulam apabila terdapat bibit yang mati setelah pindah tanam. Pengunaan benih yang lebih tinggi pada usahatani padi tadah hujan dikarenakan petani lahan kering merasa lebih membutuhkan banyak benih untuk usahataninya. 


\section{Penggunaan Urea}

Berdasarkan uji t-test terdapat perbedaan dalam penggunaan urea untuk usahatani padi irigasi P2AT dengan usahatani padi tadah hujan. Rata-rata urea yang digunakan untuk lahan irigasi P2AT sebesar 341,25 sedangkan penggunaan urea pada lahan tadah hujan yang sebesar 439,08 . Penggunaan pupuk urea pada usahatani padi tadah hujan lebih tinggi jika dibandingkan dengan penggunaan pupuk urea pada usahatani padi lahan tadah hujan. Penggunaan pupuk urea pada usahatani padi irigasi lebih sedikit karena sistem pengairannya yang sudah baik sehingga waktu pemupukannya terjadwal dengan baik, berbeda dengan usahatani tadah hujan dimana pemupukannya harus menyesuaikan kondisi air di lahan.

\section{Penggunaan SP36}

Berdasarkan Tabel 4 menunjukkan bahwa tidak ada perbedaan yang nyata untuk penggunaan SP36 pada usahatani padi irigasi P2AT dengan usahatani padi tadah hujan. Penggunaan pupuk SP36 relatif sama antara lahan irigasi P2AT dengan lahan tadah hujan, karena petani menganggap pupuk SP36 hanya pupuk tambahan, sehingga hanya digunakan seperlunya saja.

\section{Penggunaan Pestisida}

Nilai signifikansi dari hasil uji t-test 0,001 $<0,05$ menunjukkan bahwa terdapat perbedaan yang nyata antara penggunaan pestisida pada lahan irigasi P2AT dengan lahan tadah hujan. Penggunaan pestisida pada lahan irigasi lebih tinggi dibandingkan penggunaan pestisida pada lahan tadah hujan. Rata-rata penggunaan pestisida pada lahan irigasi sebesar 0,434 liter/ha. sedangkan pada lahan tadah hujan rata-rata penggunaan pestisidanya sebesar 0,36 liter/ha.. Penggunaan pestisida pada lahan tadah hujan lebih sedikit untuk menekan biaya yang dikeluarkan. Perbedaan penggunaan pestisida juga dipengaruhi oleh benih yang ditanam. Penggunaan benih yang ungul dan bersertifikat akan lebih tahan terhadap hama dan penyakit.

\section{Penggunaan Tenaga Kerja}

Dari tabel uji t-test dapat dilihat bahwa tidak terdapat perbedaan yang nyata antara penggunaan tenaga kerja untuk usahatani padi irigasi P2AT dengan usahatani padi lahan tadah hujan. Penggunaan tenaga kerja relatif sama karena baik usahatani padi lahan irigasi P2AT maupun lahan tadah hujan sudah sama-sama menggunakan teknologi traktor untuk mengolah lahan. Tenaga kerja dalam usahatani padi lebih banyak dibutuhkan saat pengolahan lahan, penanaman dan panen. Untuk pemupukan, penyemprotan pestisida dan penyiangan lebih banyak dikerjakan sendiri.

\section{SIMPULAN}

Pendapatan usahatani padi lahan irigasi P2AT lebih besar (Rp. 17.892.096) dibandingkan usahatani padi tadah hujan (Rp. 13.209.235). Berdasarkan nilai R/C rasio, usahatani padi lahan irigasi dan tadah hujan tidak berbeda nyata dengan masing-masing nilai $R / C$ rasio sebesar 2,43 dan 2,38. Produktivitas padi di Desa Kutukan dipengaruhi oleh jenis lahan, pupuk urea dan tenaga kerja serta terdapat perbedaan dalam penggunaan bibit, urea, dan pestisida pada usahatani padi lahan irigasi P2AT dengan lahan tadah hujan, sedangkan penggunaan SP36 dan tenaga kerja relatif sama.

Untuk kedepannya, jika ingin meneliti tentang efisiensi padi di Desa Kutukan sebaiknya mengkaji musim tanam pertama dan kedua serta memperhitungkan semua tenaga kerja yang digunakan baik tenaga kerja keluarga maupun tenaga kerja luar kelurga. Pengguaan tenaga kerja memberikan pengaruh terhadap produktivitas padi maka sebaiknya keterampilan petani lebih ditingkatkan lagi, sedangkan penggunaan urea 
memberikan pengaruh yang negatif terhadap produktivitas padi maka sebaiknya penggunaannya dikurangi untuk meningkatkan produktivitas padi.

\section{DAFTAR PUSTAKA}

Ahmadi. 2001. IImu Usahatani. Jakarta: Penebar Swadaya.

Apriyantono, A. 2007. Acuan Penetapan Rekomendasi Pupuk N, P, dan K pada Lahan Sawah Spesifik Lokasi (Per Kecamatan). Jakarta: Kementerian Pertanian RI.

Arifin, B. 2007. Diagnosis Ekonomi Politik Pangan dan Pertanian. Jakarta: Rajagrafindo Persada.

Badan Penelitian dan Pengembangan Pertanian. 2005. Prospek dan Arah Pengembangan Agribisnis Padi. Badan Penelitian dan Pengembangan Pertanian, Departemen Pertanian.

Daniel, \& Moehar. 2004. Pengantar Ekonomi Pertanian. Jakarta: bumi aksara.

Fermadi, O., Prasmatiwi, F. E., \& Kasymir, E. 2015. Analisis Efisiensi Produksi Dan Keuntungan Usahatani Jagung Di Kabupaten Ogan Komering Ulu Timur Sumatera Selatan. JIIA, 3(1), 107-113.

Gaspersz, V. 2006. Continous Cost Reduction Through Lean-Sigma Approach. Jakarta: PT. Gramedia Pustaka Utama.

Hernanto, F. 1991. Ilmu usahatani. Jakarta: Penebar Swadaya.

Hidayat, F., \& Muis, A. 2014. Usahatani Padi Sawah Irigasi Setengah Teknis Dan Irigasi Desa Di Desa Pakuli Kecamatan Gumbasa. E-J. Agrotekbis, 2(April), 193-198.

Indah, L. S. M., Zakaria, W. A., \& Prasmatiwi, F. E. 2015. Analisis Efisiensi Produksi dan Pendapatan Usahatani Padi Sawah Pada Lahan Irigasi Teknis Dan Lahan Tadah Hujan Di Kabupaten Lampung Selatan. JIIA, 3(3), 260-267.

Ken Suratiyah, I. M. S. 2015. IImu Usaha Tani (Edisi Revisi). Jakarta: Penebar Swadaya Grup.

Mubyarto. 2002. Pengantar Ekonomi Pertanian. Jakarta: LP3ES.

Noviani, E., Hasanah, U., \& Wicaksono, I. A. 2018. Studi Komparatif Usahatani Padi Sawah Irigasi Dan Usahatani Padi Sawah Tadah Hujan (Studi Kasus di Kecamatan Grabag Kabupaten Purworejo). Surya Agritama : Jurnal Ilmu Pertanian Dan Peternakan, 7(1).

Prasetya T. 2006. Penerapan Teknologi Sistem Usaha tani Tanaman-Ternak Melalui Pendekatan Organisasi Kelompok Tani (Suatu Model Pengelolaan Lingkungan Pertanian). Surakarta: Fakultas Pertanian Universitas Sebelas Maret.

Rahim, \& Retno, D. 2007. Ekonomika Pertanian. Jakarta: Penebar Swadaya.

Sitinjak, W. 2019. Analisis Komparasi Pendapatan Usahatani Padi Sawah Sistem Irigasi dengan Sistem Tadah Hujan. Jurnal Integritas, 5(1), 1-9.

Soekartawi. 2002. Analisis Usahatani. Jakarta: Raja Grafindo Persada.

Soekartawi. 2003. Teori Ekonomi Produksi dengan Bahasan Analisis Fungsi Produksi Cobb-Douglass. Jakarta: PT Raja Grafindo Persada.

Wibowo, L. S. 2012. Analisis Efisiensi Alokatif Faktor-Faktor Produksi dan Pendapatan Usahatani Padi (Oryza sativa L.) (Studi Kasus di Desa Sambirejo, Kecamatan Saradan, Kabupaten Madiun). Skripsi. Malang: Universitas Brawijaya (Dipublikasikan). 
Widodo, Sri. 1989. Production efficiency of rice farmers in Java-Indonesia. Yogyakarta: Gadjah Mada University Press.

Yoko, B., Syaukat, Y., \& Fariyanti, A. 2014. Analisis Efisiensi Usahatani Padi Di Kabupaten Lampung Tengah. Jurnal Agribisnis Indonesia, 2(2), 127-140. 